\title{
Powikłania w kardiochirurgii: rozejścia mostka po pośrodkowej sternotomii. Analiza wyników 14171 operacji kardiochirurgicznych wykonanych w latach 1990-2009
}

\section{Complications of cardiac surgery: sternal dehiscence after median sternotomy. Analysis of 14,173 cases operated on in years 1990-2009}

\author{
Mariusz Listewnik', Arkadiusz Kazimierczak², Krzysztof Mokrzycki \\ ${ }^{1}$ Klinika Kardiochirurgii Pomorskiego Uniwersytetu Medycznego w Szczecinie \\ al. Powstańców Wlkp. 72, 70-111 Szczecin \\ Kierownik: prof. dr hab. n. med. Mirosław Brykczyński \\ ${ }^{2}$ Klinika Chirurgii Ogólnej i Naczyniowej Pomorskiego Uniwersytetu Medycznego w Szczecinie \\ al. Powstańców Wlkp. 72, 70-111 Szczecin \\ Kierownik: prof. dr hab. n. med. Piotr Gutowski
}

\section{SUMMARY}

Introduction: Dehiscence of the sternum is one of the most serious complications following cardiac surgery. It occurs after $0.2-5 \%$ of interventions with sternotomy access.

Aim: The evaluation of factors that may influence the frequency of this complication.

Material and methods: A retrospective review of 14,171 patients undergoing median sternotomy for cardiac surgery between 1990 and 2009 at the Cardiac Surgery Department of the Pomeranian Medical University in Szczecin (Poland) was performed. The studied group consisted of 3,999 women (28.2\%) and 10,172 men $(71.8 \%)$ aged $11-87$ years (59.8 years on average). We analysed cases with sternal dehiscence (SD), which occurred in 298 (2.1\%) of the patients.

Results: The significant risk factors were: male sex ( $p=0.0003)$ age $(p<0.00006)$, body mass $(p<0.00007)$, and use of both internal thoracic arteries $(\mathrm{p}<0.00001)$. The risk of SD was also increased by coexisting diabetes and chronic obstructive lung disease $(p<0.012$ and $p<0.02$ respectively); however, discriminant analysis revealed that these variables were only linked to age. Apart from CABG, the type of surgical intervention had no influence on the frequency of SD. The total length of hospital stay in patients with SD was more than two times longer than in the rest of the patients $(\mathrm{p}<0.00001)$. However, there were no significant differences in postoperative mortality between these two groups $-4.4 \%$ in the group with SD and $4.2 \%$ in the group without it.

Conclusions: Not being able to eliminate the influence of risk factors, since 2010 we decided to introduce changes in the method of sternum closure by increasing the number of wire loops from 6 to at least 8 . For patients heavier than $80 \mathrm{~kg}$, we assumed a ratio of one additional loop per every $10 \mathrm{~kg}$ of body mass, which should result in improved sternum stabilisation and reduce the risk of dehiscence.

Key words: sternum, risk factors, CABG, internal thoracic artery.

\section{STRESZCZENIE}

Wstęp: Rozejście się mostka należy do poważnych powikłań po operacji kardiochirurgicznej i występuje po 0,2-5\% zbiegów dokonywanych z dostępu przez sternotomię.

Celem pracy była ocena czynników mogących wpływać na częstość wystąpienia tego powikłania.

Materiał i metody: Badaniami objęto 14171 pacjentów operowanych w Klinice Kardiochirurgii Pomorskiego Uniwersytetu Medycznego w Szczecinie (PUM) z dostępu przez sternotomię w latach 1990-2009. W badanej grupie było 3999 (28,2\%) kobiet i 10172 (71,8\%) mężczyzn w wieku 11-87 (śr. 59,8) lat. Analizie poddano rozejścia mostka, które wystąpiły u 298 (2,1\%) pacjentów.

Wyniki: Istotnymi czynnikami ryzyka okazały się: płeć męska ( $p=0,0003)$, wiek $(\mathrm{p}<0,00006)$, masa ciała $(\mathrm{p}<0,00007)$ i użycie obu tętnic piersiowych wewnętrznych $(\mathrm{p}<0,00001)$. Występowanie cukrzycy i przewlekłej zaporowej choroby płuc również wpływało na zwiększenie ryzyka rozejścia mostka $(\mathrm{p}<0,012$ i p < 0,02), jednak analiza dyskryminacyjna wykazała związek tych zmiennych tylko z wiekiem chorych. Poza pomostowaniem tętnic wieńcowych rodzaj operacji nie miał wpływu na częstość rozejść. Łączny czas pobytu w szpitalu pacjentów z rozejściem mostka był ponad dwukrotnie dłuższy niż pozostałych ( $p<0,00001)$. Nie było natomiast istotnych różnic w śmiertelności pooperacyjnej pomiędzy tymi grupami - 4,4\% w grupie z rozejściem mostka i $4,2 \%$ w grupie bez rozejść.

Wniosek: Nie mogąc zniwelować wpływu czynników ryzyka, od 2010 r. postanowiono wprowadzić zmiany w sposobie zespolenia mostka w postaci zwiększenia liczby zakładanych pętli drucianych z 6 do co najmniej 8, przyjmując dla pacjentów cięższych niż 80 kg wskaźnik: 1 pętla na 10 kg ciężaru ciała, co powinno dać lepszą stabilizację mostka i zmniejszyć ryzyko rozejścia. Słowa kluczowe: mostek, czynniki ryzyka, CABG, tętnica piersiowa wewnętrzna. 


\section{WSTEP}

Podłużne przecięcie mostka jest najłatwiejszym sposobem dotarcia do śródpiersia przedniego i serca, dlatego powszechnie stosuje się ten dostęp podczas operacji kardiochirurgicznych, transplantacji serca i niektórych zabiegów torakochirurgicznych. Rozejście się mostka po sternotomii zalicza się do bardzo poważnych powikłań pooperacyjnych. Występuje po 0,2-5\% operacji i wiąże się ze wzrostem śmiertelności okołooperacyjnej $[1,2]$. Rozejście się mostka może nastąpić niemal natychmiast po operacji, zarówno w wyniku postępowania resuscytacyjnego po nagłym zatrzymaniu krążenia, jak i kilka lat od zabiegu, po banalnym upadku z roweru. Jednak wyznaczenie choćby przybliżonej cezury czasowej dla podziału na rozejścia wczesne i późne jest dość trudne. Dla celów statystycznych przyjęto, że za rozejścia wczesne uznaje się wszystkie przypadki, które nastąpiły przed upływem 30. doby oraz w dowolnym terminie, o ile pacjent nie opuścił oddziału lub powrócił nań przed upływem 30 dni od operacji. Rozejścia, do których doszło po opuszczeniu Kliniki Kardiochirurgii Pomorskiego Uniwersytetu Medycznego w Szczecinie (PUM) po upływie 30. doby od operacji zaliczono do powikłań odległych.

Należy pamiętać, że pierwsza faza rozejścia zachodzi często skrycie i dopiero wyraźny dyskomfort oddechowy, wyciek płynnej treści z rany po sternotomii lub rozejście się skóry nad mostkiem bywają pierwszymi widocznymi objawami powikłania. Niekiedy sam pacjent zgłasza odczuwalne tarcie lub przeskakiwanie krawędzi mostka, ewentualnie zostaje to stwierdzone podczas rutynowego badania podczas obchodu.

Wiele przyczyn i czynników, zarówno wewnętrznych, jak i zewnętrznych, przed-śród- i pooperacyjnych może inicjować lub sprzyjać rozejściu się mostka. Za czynniki przedoperacyjne, zwiększające ryzyko rozejścia mostka po operacji uważa się palenie tytoniu, przewlekła obturacyjna choroba płuc (POCHP), otyłość, cukrzycę, osteoporozę i ciężką niewydolność krążenia. Działania śródoperacyjne - użycie jednej lub obu tętnic piersiowych wewnętrznych podczas operacji, długi czas krążenia pozaustrojowego - również uważane są za czynniki zwiększające ryzyko rozejścia mostka. Zazwyczaj pomijaną, bo trudną do ustalenia przyczyną może być błąd techniczny podczas zamykania mostka, a w okresie pooperacyjnym, obok masażu pośredniego serca do rozejścia mostka może przyczynić się nagły i silny atak pobudzenia psychicznego, uporczywy kaszel, stosowanie niektórych leków (inhibitory ACE, immunosupresja), masywne przetoczenia krwi w okresie okołooperacyjnym oraz nadmierne wydzielanie płynu przez worek osierdziowy lub krwiak w worku osierdziowym, powodujące osłabienie struktury mostka $[1,3,4,5,6]$. Zarówno te ostatnie, jak i przeprowadzane ze wskazań nagłych powtórne operacje zwiększają ryzyko zakażenia rany i również mogą prowadzić do rozejścia się mostka $[7,8]$.

Celem przeprowadzonych badań była analiza czynników mogących wpływać na częstość wystąpienia rozejścia mostka u pacjentów operowanych w Klinice Kardiochirurgii PUM w okresie 20 lat, a także próba ustalenia metod postępowania wpływających na zmniejszenie tego ryzyka.
Dokonano porównania grup z rozejściem mostka i bez, przeprowadzając analizę czynników demograficznych, schorzeń współistniejących i danych okołooperacyjnych. Podstawę stanowiły informacje zawarte w Klinicznej Bazie Danych, prowadzonej od początku $1990 \mathrm{r}$.

Analizę statystyczną przeprowadzono przy użyciu licencjonowanego programu Statistica 10 (StatSoft, Inc. Tulsa, OK, USA). Zastosowano test $\chi^{2}$, test $t$, test U Manna-Whitneya i krokową analizę funkcji dyskryminacyjnej. Wyniki zostały przedstawione w postaci procentowej oraz średniej \pm SD. Istotność statystyczna została określona przy wartości $\mathrm{p}<0,05$.

\section{MATERIA I METODY}

Badaniem retrospektywnym objęto wszystkich pacjentów operowanych z dostępu przez sternotomię pomiędzy 1.01.1990 r. a 31.12.2009 r. Na 14171 wykonanych sternotomii rozejście mostka wystąpiło u 308 (2,2\%) chorych. Z tej grupy wyłączono 10 pacjentów, u których do rozejścia doszło pomiędzy o. a 4. dobą pooperacyjną wskutek prowadzonej resuscytacji po nagłym zatrzymaniu krążenia. Grupę kontrolną stanowili pozostali pacjenci operowani w tym samym okresie, u których nie wystąpiło rozejście mostka. Do tej grupy dołączono także 10 ww. pacjentów z rozejściem w wyniku przeprowadzonej resuscytacji.

W latach 1990-2009 u wszystkich chorych stosowano podczas pierwotnego zamknięcia 6 pojedynczych pętli drucianych zakładanych przez kość mostka lub przez międzyżebrza (przy wąskich mostkach). Podczas zamknięć wtórnych stosowano różne techniki - 6 pojedynczych lub podwójnych pętli, zaopatrzenie sposobem Martineza, Robitseka, a także stalowe taśmy.

W badanej grupie było 10172 (71,8\%) mężczyzn w wieku 59,1 $\pm 10,0$ lat i $3999(28,2 \%)$ kobiet $w$ wieku $61,6 \pm 10,1$ lat. W obu grupach nadwaga występowała nieco częściej u mężczyzn. Wartość BMI pomiędzy 25 a 30 zanotowano u $5534(54,4 \%)$ mężczyzn i $1800(45,0 \%)$ kobiet, za to otyłość częściej zaobserwowano właśnie u kobiet: BMI 30-35 u 910 (22,8\%) kobiet wobec 2011 (19,8\%) mężczyzn, a BMI > 35 u odpowiednio $160(4,0 \%)$ i 164 $(1,6 \%)$. Różnice były istotne statystycznie we wszystkich podgrupach. Natomiast średnie wartości BMI dla całej grupy kobiet i mężczyzn nie różniły się istotnie.

Z chorób współistniejących cukrzyca wstępowała u 2728 (19,6\%), znamiennie częściej u kobiet - 878 (22,0\%) niż u mężczyzn - 1850 (18,2\%). Natomiast nie było różnic w częstości występowania POCHP - zanotowano 417 (2,9\%) przypadków, w tym 287 (2,8\%) u mężczyzn i 130 (3,2\%) u kobiet. Dane demograficzne i kliniczne obu grup zestawiono w tabeli 1.

Najczęściej wykonywaną operacją było pomostowanie tętnic wieńcowych w krążeniu pozaustrojowym, które wykonano u 11415 (80,6\%) pacjentów. U 8914 (62,9\%) były to izolowane pomosty aortalno-wieńcowe wykonane w krążeniu pozaustrojowym, u 1091 (7,7\%) była to operacja skojarzona - pomosty i operacja wady zastawkowej lub tętniaka aorty, a u 1410 (9,9\%) pomostowanie na bijącym sercu bez krążenia pozaustrojowego. Rodzaje wykonanych operacji przedstawiono w tabeli 2. 
TABELA 1. Przedoperacyjne dane epidemiologiczne

\begin{tabular}{|c|c|c|c|c|}
\hline \multicolumn{2}{|c|}{ Dane przedoperacyjne } & \multirow{2}{*}{$\frac{\text { Liczba }}{10172}$} & \multirow{2}{*}{$\frac{\%}{71,8}$} & \multirow[t]{2}{*}{ Statystyka } \\
\hline \multirow{2}{*}{ Płeć } & mężczyźni & & & \\
\hline & kobiety & 3999 & 28,2 & - \\
\hline \multicolumn{2}{|c|}{ Wskaźnik M/K } & $2,54: 1$ & - & - \\
\hline \multicolumn{2}{|l|}{ Wiek } & $59,8 \pm 10,1$ & - & - \\
\hline \multirow{2}{*}{ Wiek } & mężczyźni & $59,1 \pm 10,0$ & - & \multirow{2}{*}{$p<0,00001$} \\
\hline & kobiety & $61,6 \pm 10,1$ & - & \\
\hline \multicolumn{2}{|l|}{ BMI } & $27,39 \pm 3,67$ & - & - \\
\hline \multirow{2}{*}{ Nadwaga } & mężczyźni & 5534 & 54,4 & \multirow{2}{*}{$p<0,00001$} \\
\hline & kobiety & 1800 & 45,0 & \\
\hline \multirow{2}{*}{ Otyłość } & mężczyźni & 2011 & 19,8 & \multirow{2}{*}{$p<0,00008$} \\
\hline & kobiety & 910 & 22,8 & \\
\hline \multirow{2}{*}{$\begin{array}{l}\text { Znaczna } \\
\text { otyłość }\end{array}$} & mężczyźni & 160 & 1,6 & \multirow{2}{*}{$p<0,00001$} \\
\hline & kobiety & 164 & 4,1 & \\
\hline \multirow{2}{*}{ BMI } & mężczyźni & $27,37 \pm 3,40$ & - & \multirow{2}{*}{$p=0,35$} \\
\hline & kobiety & $27,44 \pm 4,28$ & - & \\
\hline \multicolumn{2}{|l|}{ Cukrzyca } & 2728 & 19,6 & - \\
\hline \multirow{2}{*}{ Cukrzyca } & mężczyźni & 1850 & 18,2 & \multirow{2}{*}{$p<0,00001$} \\
\hline & kobiety & 878 & 22,0 & \\
\hline POCHP & & 417 & 2,9 & - \\
\hline \multirow{2}{*}{ POCHP } & mężczyźni & 287 & 2,8 & \multirow{2}{*}{$p=0,22$} \\
\hline & kobiety & 130 & 3,2 & \\
\hline
\end{tabular}

TABELA 2. Rodzaje wykonanych operacji

\begin{tabular}{lccc}
\multicolumn{1}{c}{ Rodzaj operacji } & $\begin{array}{c}\text { Liczba } \\
\text { operacji }\end{array}$ & $\begin{array}{c}\text { Liczba } \\
\text { rozejść }\end{array}$ & \% \\
\hline OPCAB & 1410 & 24 & 1,7 \\
\hline CABG & 8914 & 211 & 2,4 \\
\hline $\begin{array}{l}\text { CABG skojarzone z operacją } \\
\text { zastawkową }\end{array}$ & 1091 & 29 & 2,7 \\
\hline $\begin{array}{l}\text { Operacje zastawki aortalnej } \\
\text { Operacje zastawki mitralnej }\end{array}$ & 1102 & 11 & 1,0 \\
\hline $\begin{array}{l}\text { Operacje zastawek mitralnej i aortalnej } \\
\text { Operacje tętniaków i rozwarstwień }\end{array}$ & 306 & 5 & 1,6 \\
\hline $\begin{array}{l}\text { aorty wstępującej i/lub łuku } \\
\text { Pozostałe operacje z dostępu przez }\end{array}$ & 189 & 4 & 2,1 \\
\hline sternotomię & 287 & 2 & 0,7 \\
\hline Razem & 14171 & 298 & 2,1 \\
\hline
\end{tabular}

Wśród chorych, którym wykonano pomostowanie tętnic wieńcowych, u $9709(68,5 \%)$ użyto oprócz pomostów żylnych jednej tętnicy piersiowej wewnętrznej (t.p.w.). U 934 (6,6\%) użyto dwóch t.p.w., a u $772(5,4 \%)$ rewaskularyzację serca wykonano bez t.p.w. (pomosty z żyły odpiszczelowej, tętnicy promieniowej lub żołądkowo-sieciowej prawej). W obliczeniach wzięto także pod uwagę przypadki, w których pobrana t.p.w. nie nadawała się do wykorzystania i wykonano tylko pomosty żylne lub w miejsce uszkodzonej tętnicy pobrano drugostronną. Tych pacjentów doliczono odpowiednio do grupy z użytą jedną lub dwiema t.p.w.

Do grupy badanej zaliczono 298 (2,1\%) pacjentów, u których wykonano 355 operacji powtórnego zszycia mostka. Jednokrotnego powtórnego zespolenia mostka wymagało 253 pacjentów,
35 - dwukrotnego, 8 - trzykrotnego, a 2 - czterokrotnego. Kolejne rozejścia mostka u tego samego pacjenta traktowano jako część tego samego procesu i w obliczeniach statystycznych liczono jako jeden przypadek. U 261 (87,6\%) pacjentów rozejście mostka wystąpiło jako powikłanie wczesne, a u 37 $(12,4 \%)$ - jako odległe. W tej drugiej grupie, u 27 pacjentów odległe rozejście i zespolenie mostka było pierwszą procedurą wykonaną po operacji podstawowej, a 9 chorych było przynajmniej raz reperowanych we wczesnym okresie pooperacyjnym z powodu krwawienia (2) i/lub rozejścia mostka (7). W grupie powikłań wczesnych czas od operacji do wykonania powtórnego lub ostatecznego zespolenia mostka wyniósł 16,7 $\pm 15,5$ dnia, podczas gdy w grupie rozejść odległych $-422 \pm 477,6$ dni.

Europejska skala ryzyka (Euroscore logistic - ESL) stosowana jest również w Polsce dla oszacowania przewidywanego ryzyka zgonu podczas operacji kardiochirurgicznych. Średnia wartość ESL wyniosła 5,43 \$7,42.

\section{WYNIKI}

Analizując częstość wystąpienia rozejścia mostka zależnie od płci stwierdzono, że u mężczyzn powikłanie to występuje blisko dwa razy częściej. Stosunek liczby mężczyzn do kobiet w grupie z rozejściem mostka wyniósł $4,3: 1$, podczas gdy w grupie bez tego powikłania - 2,5:1. Różnice były istotne statystycznie. Wiek pacjentów również wpływał na częstość występowania rozejść mostka. Zarówno w całej grupie, jak i przy podziale według płci, pacjenci w grupie z rozejściem mostka byli istotnie starsi. Wskaźnik masy ciała pacjentów (BMI) wyrażający stosunek wagi do wzrostu stanowił również istotny czynnik obciążający. Zarówno w całej badanej grupie, jak i wśród mężczyzn i kobiet wartość BMI była znamiennie wyższa w grupie z rozejściem mostka. Cukrzyca i przewlekła obturacyjna choroba płuc (POCHP) uważane są za czynniki mogące wpływać na częstość rozejścia się mostka. Istotnie częstsze występowanie rozejść wśród chorych z cukrzycą stwierdzono w całej grupie badanej oraz wśród mężczyzn. Natomiast w grupie kobiet, różnice nie były istotne statystycznie. Wśród chorych z rozpoznanym POCHP częstość rozejść była również istotnie wyższa w całej grupie i u kobiet, natomiast u mężczyzn różnice te nie były istotne statystycznie. Wyniki zestawiono w tabeli 3 .

Przeprowadzona analiza funkcji dyskryminacyjnej badanych czynników demograficznych wykazała, że jedynie trzy czynniki - płeć, wiek i BMI stanowiły niezależne czynniki rozejścia się mostka. Częstość występowania cukrzycy i POCHP, związana była z wiekiem pacjentów i nie wykazano ich istotnego wpływu na częstość wystąpienia powikłania.

Analiza częstości rozejść mostka zależnie od typu wykonanej operacji wykazała, że poza pomostowaniem tętnic wieńcowych rodzaj operacji nie miał wpływu na częstość rozejść mostka.

Pomostowanie tętnic wieńcowych było wykonywane z użyciem dwóch technik operacyjnych - w krążeniu pozaustrojowym (CABG) i „na bijącym sercu”, bez krążenia pozaustrojowego (OPCAB). Badając częstość występowania rozejść mostka 
TABELA 3. Czynniki ryzyka pooperacyjnego rozejścia mostka

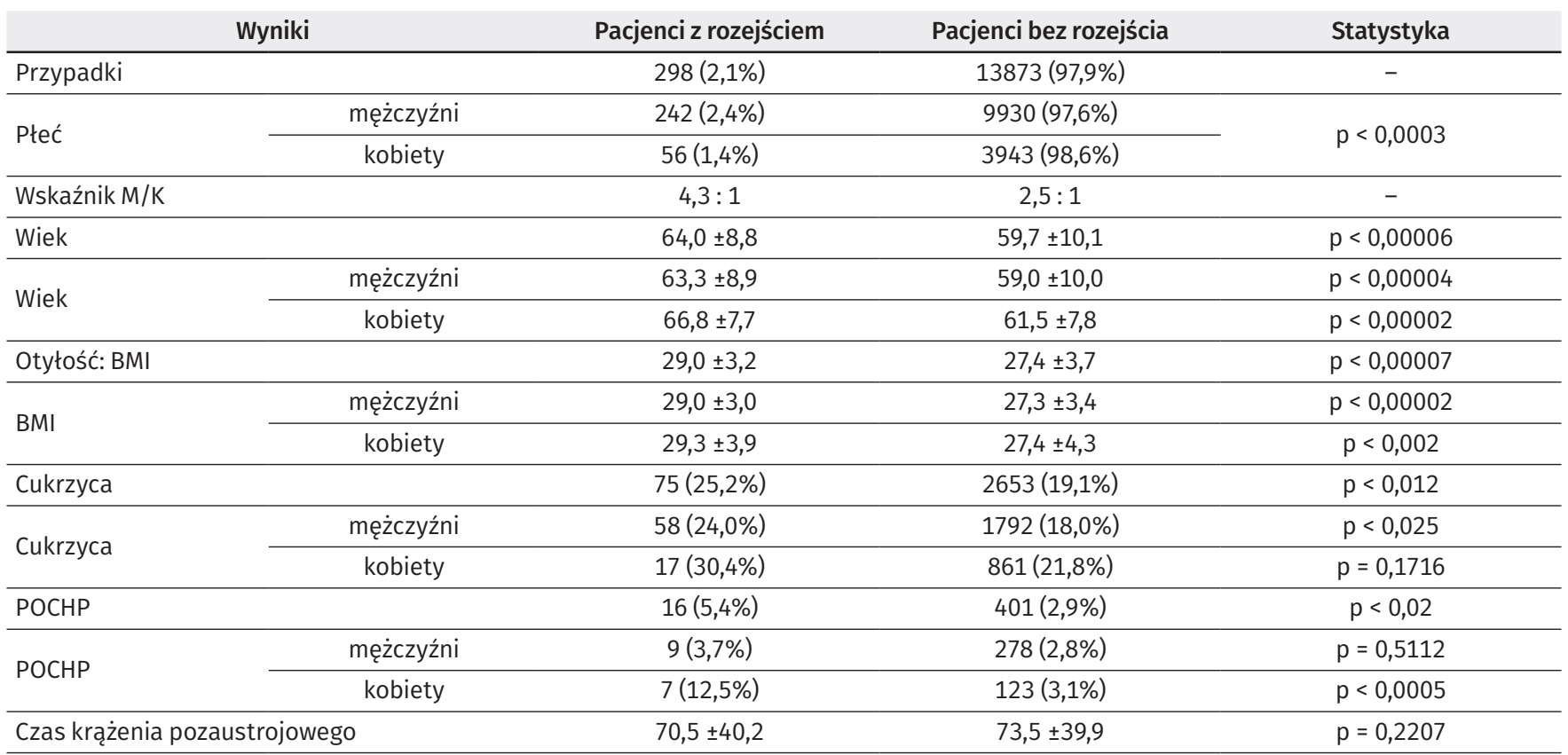

TABELA 4. Wpływ użycia tętnicy piersiowej wewnętrznej na częstość rozejść mostka

\begin{tabular}{|c|c|c|c|c|c|}
\hline \multirow[b]{2}{*}{ Materiał pomostów } & \multirow{2}{*}{$\begin{array}{c}\% \\
\text { rozejść }\end{array}$} & \multicolumn{4}{|c|}{ Istotność } \\
\hline & & 1 t.p.w. & 0 t.p.w. & pozostałe operacje & $\begin{array}{l}\text { pozostałe operacje } \\
+0 \text { t.p.w. }\end{array}$ \\
\hline 1 t.p.w. & $2,1 \%$ & - & $p=0,3935$ & $p<0,003$ & $p<0,003$ \\
\hline 0 t.p.w. & $1,7 \%$ & $p=0,3935$ & - & $p=0,3348$ & - \\
\hline Pozostałe operacje & $1,2 \%$ & $p<0,003$ & $p=0,3348$ & - & - \\
\hline Pozostałe operacje + 0 t.p.w. & $1,3 \%$ & $p<0,003$ & - & - & - \\
\hline
\end{tabular}

w obu grupach stwierdzono, że chociaż w grupie chorych operowanych techniką off pump, czyli „na bijącym sercu” powikłanie wystąpiło rzadziej, to jednak różnice nie osiągnęły istotności statystycznej. Wynik nie zależał od faktu czy operacje wykonane techniką OPCAB porównano wyłącznie z CABG $(1,7 \% \mathrm{v}$. $2,4 \% ; p=0,1169)$, czy z CABG wraz z operacjami skojarzonymi (1,7\% v. $2,7 \% ; p=0,2965)$.

Istotnym elementem mogącym wpływać na gojenie się mostka jest użycie t.p.w. do pomostowania naczyń wieńcowych. Pacjentów oceniono w trzech grupach. W pierwszej grupie wykonano wyłącznie pomosty żylne lub z tętnicy promieniowej, w drugiej użyto jednej, a w trzeciej - obu t.p.w. Analiza statystyczna wykazała, że najmniej rozejść mostka wystąpiło wśród chorych, u których nie użyto tętnicy piersiowej wewnętrznej $(1,7 \%)$, gorszy wynik zaobserwowano w grupie $\mathrm{z}$ użytą jedną tętnicą piersiową wewnętrzną $(2,1 \%)$, a najgorszy w grupie trzeciej, gdzie użyto obu tętnic $(4,6 \%)$. Wyniki przedstawiono w tabeli 4 .

Wystąpienie rozejścia mostka wpływało na wydłużenie czasu pobytu chorych na oddziale. Średni czas pobytu pacjentów bez rozejścia mostka wyniósł 9,6 dni, podczas gdy w grupie z powikłaniem łącznie 22,3 dni. Różnice były istotne statystycznie. Wystąpienie powikłania nie wpłynęło natomiast istotnie na śmiertelność okołooperacyjną. W grupie bez rozejścia mostka odsetek zgonów wyniósł 4,2, podczas gdy u chorych z powikłanym gojeniem się mostka - 4,4. Różnice między grupami nie były istotne statystycznie. Obie wartości były natomiast niższe od średnich wyników ESL w obu grupach. Wyniki przedstawiono $\mathrm{w}$ tabeli 5 .

TABELA 5. Czas pobytu i śmiertelność okołooperacyjna

\begin{tabular}{lccc}
\multicolumn{1}{c}{ Zmienna } & $\begin{array}{c}\text { Bez rozejścia } \\
\text { mostka }\end{array}$ & $\begin{array}{c}\text { Z rozejściem } \\
\text { mostka }\end{array}$ & Istotność \\
\hline Czas pobytu (dni) & $9,6 \pm 6,6$ & $22,3 \pm 22,3$ & $\mathrm{p}<0,00001$ \\
\hline Zgon & $585(4,2 \%)$ & $13(4,4 \%)$ & $\mathrm{p}=0,9015$ \\
\hline $\mathrm{ESL}$ & 6,3 & 5,4 & $\mathrm{p}=0,205$ \\
\hline
\end{tabular}

\section{DYSKUSJA}

W 1957 r. Julian i wsp. zaproponowali nowy sposób dostępu do przedniego śródpiersia przez podłużną, pośrodkową sternotomię [9]. Przedstawiona technika w krótkim czasie została uznana za optymalną metodę odsłaniania serca do operacji kardiochirurgicznych w krążeniu pozaustrojowym. Wraz 
z jej rozpowszechnieniem pojawiły się także powikłania z nią związane, w tym rozejścia mostka, w których śmiertelność - gdy doszło jednocześnie do głębokiego zakażenia śródpiersia - sięgała 50\%. Choć w latach 60. ubiegłego wieku operacje kardiochirurgiczne były wykonywane stosunkowo rzadko i w nielicznych ośrodkach, już w 1963 r. wdrożono leczenie sposobem zamkniętym z użyciem drenażu przepływowego roztworem antybiotyku, co pozwoliło obniżyć wskaźnik zgonów w najcięższych przypadkach do $20 \%$ [10]. Od końca lat 60. XX w., wraz z szybko rosnącą liczbą operacji wieńcowych, rozpoczęły się szeroko zakrojone badania mające na celu ustalenie czynników wpływających na częstość pooperacyjnych rozejść mostka. Do chwili obecnej rozpoznano przynajmniej kilkanaście z nich, mogących bezpośrednio lub pośrednio wpływać na częstość rozejść mostka. Wiadomo, że powikłanie występuje częściej u mężczyzn ze względu na umięśnienie klatki piersiowej, ale także u kobiet z dużym rozmiarem piersi, u pacjentów z nadwagą, cukrzycą, u przewlekle pobierających sterydy, poddawanych leczeniu immunosupresyjnemu, palących tytoń czy chorujących na POCHP. Podwyższone ryzyko rozejścia mostka występuje także u pacjentów w podeszłym wieku [2, 11, 12]. Z czynników okołooperacyjnych, już na samym początku wprowadzenia techniki pośrodkowego otwarcia mostka wskazywano na wagę prawidłowego wykonania cięcia [3, 13]. Poważniejsze wyjście poza oś symetrii mostka często skutkuje powikłanym gojeniem. Podobny efekt mogą spowodować błędy w technice zespalania mostka $[1,13]$. Poza tym wykazywano wpływ czasu trwania operacji i ekspozycji śródpiersia, użycia hipotermii, krążenia pozaustrojowego, zwiększonych przetoczeń krwi, reoperacji z powodu krwawienia, a przede wszystkim - użycia jednej, a zwłaszcza obu tętnic piersiowych wewnętrznych podczas operacji, choć wpływ tego ostatniego czynnika bywa negowany [14, 15, 16]. Wśród czynników pooperacyjnych na częstość rozejść może wpływać uciskanie klatki piersiowej podczas resuscytacji, nasilony kaszel, który występuje u palaczy tytoniu czy chorych z POCHP, ale także może być spowodowany pobieraniem określonych leków (np. kaptopryl) [17]. Również inne powikłania płucne skutkujące silnym kaszlem (np. zapalenie płuc), a także przedłużony okres intubacji i wentylacji mechanicznej mogą zwiększać ryzyko rozejścia mostka. Najgroźniejszym powikłaniem często współistniejącym z rozejściem mostka jest zakażenie rany, tkanek miękkich, mostka i śródpiersia [14, 15, 16, 18].

Zapobieganie rozejściom polega głównie na próbie eliminacji tych czynników, na które możemy mieć wpływ, np. na zaprzestaniu palenia tytoniu przez pacjenta przynajmniej na miesiąc przed operacją, czy zmniejszeniu masy ciała. Użycie właściwych technik przy otwarciu i zamknięciu klatki piersiowej również ma niebagatelne znaczenia. Zakażenie rany operacyjnej i rozejście mostka to dwa powikłania ściśle ze sobą powiązane, choć rzadko udaje się ustalić, które było przyczyną pierwotną. Dlatego właściwe postępowanie antyseptyczne i aseptyczne, prawidłowo prowadzona profilaktyka antybiotykowa i odpowiedni drenaż rany operacyjnej mogą mieć istotny wpływ na częstość wystąpienia tych powikłań [19]. U pacjentów z cukrzycą duże znaczenie ma pooperacyjna kontrola poziomu glikemii i moderowanie go za pomocą wlewu insuliny we wczesnym okresie po operacji i odpowiednio dobranych dawek frakcjonowanych w okresie późniejszym [20]. Wczesne uruchamianie i rehabilitacja oddechowa od momentu wybudzenia pacjenta po operacji wpływają na zmniejszenie częstości powikłań oddechowych, a co za tym idzie, także częstości rozejść mostka [8].

W materiale własnym udało się potwierdzić wpływ części z przedstawionych czynników na wystąpienie pooperacyjnego rozejścia mostka. Powikłanie wystąpiło istotnie częściej u mężczyzn, chorych w podeszłym wieku i chorych z nadwagą. U pacjentów z cukrzycą i POCHP również stwierdzono częstsze występowanie rozejść mostka, ale analiza dyskryminacyjna wskazała na związek obu tych zmiennych z wiekiem. Wydaje się, że prawidłowe prowadzenie pooperacyjne może istotnie wpływać na częstość rozejść mostka.

W okresie analizowanych 20 lat zaobserwowano rosnące trendy zarówno w odniesieniu do wieku, jak i wartości BMI operowanych chorych, które są niezależnymi czynnikami ryzyka rozejścia się mostka po operacji. Z drugiej strony, wysoki wskaźnik wykorzystania jednej lub obu tętnic piersiowych wewnętrznych wynikał z aktualnych zaleceń zarówno europejskich, jak i amerykańskich towarzystw naukowych.

Jednym ze sposobów zmniejszenia ryzyka rozejścia się mostka może być zmiana sposobu wykonywania zespolenia mostka po operacji.

\section{WNIOSKI}

Z powodu niemożliwości zniwelowania wpływu czynników ryzyka, od 2010 r. postanowiono wprowadzić zmiany w sposobie zespalania mostka w postaci zwiększenia liczby zakładanych pętli drucianych z 6 do co najmniej 8, przyjmując dla pacjentów cięższych niż 80 kg wskaźnik: 1 pętla na 10 kg ciężaru ciała, co powinno dać lepszą stabilizację mostka i zmniejszyć ryzyko rozejścia.

\section{PIŚMIENNICTWO}

1. Robicsek F., Fokin A., CookJ., Bhatia D.: Sternal instability after midline sternotomy. Thorac Cardiovasc Surg. 2000, 48 (1), 1-8.

2. LosanoffJ.E., Richman B.W., Jones J.W.: Disruption and infection of median sternotomy: a comprehensive review. Eur J Cardiothorac Surg. 2002, 21 (5), 831-839.

3. Harjula A., Jarvinen A.: Postoperative median sternotomy dehiscence. Scand J Thorac Cardiovasc Surg. 1983, 17 (3), 277-281.

4. Bitkover C.Y., Gardlund B.: Mediastinitis after cardiovascular operations: a case-control study of risk factors. Ann Thorac Surg. 1998, 65 (1), 36-40.

5. Bitner M., Jaszewski R., Mussur M., KnopikJ., Pawłowski W., Jegier B.: Całkowite rozejście się mostka po operacjach kardiochirurgicznych. Pol Przegl Chir. 1996, 68 (7), 641-645.

6. Zwoliński R., Zasłonka J., Jaszewski R., Banach M., Ostrowski S., Jegier B. et al.: Pierwotne i w tórne szycie mostka metodą Robicsek'a - doświadczenia własne. Kardiochir Torakochir Pol. 2004, 1 (2), 165-172.

7. Olbrecht V.A., Barreiro C.J., Bonde P.N., Williams J.A., Baumgartner W.A., Gott V.L. et al.: Clinical outcomes of noninfectious sternal dehiscence after median sternotomy. Ann Thorac Surg. 2006, 82 (3), 902-907. 
8. Schimmer C., Reents W., Berneder S., Eigel P., Sezer O., Scheld H. et al.: Prevention of sternal dehiscence and infection in high-risk patients: a prospective randomized multicenter trial. Ann Thorac Surg. 2008, 86 (6) 1897-1904.

9. Julian O.C., Lopez-Belio M., Dye W.S., Javid H., Grove W.J.: The median sternal incision in intracardiac surgery with extracorpore al circulation: a general evaluation of its use in heart surgery. Surgery. 1957, 42 (4), 753-761.

10. Shumacker H.B., Mandelbaum I.: Continuous antibiotic irrigation in the treatment of infection. Arch Surg. 1963, 86 (3), 384-387.

11. Milano C.A., Kesler K., Archibald N., Sexton D.J., Jones R.H.: Mediastinitis after coronary artery bypass graft surgery. Risk factors and long-term survival. Circulation. 1995, 92 (8), 2245-2251.

12. Zalewska-Adamiec M., Bachórzewska-Gajewska H., Tomaszuk-Kazberuk A., Trzciński R., Prokopczuk P., Hirnle T. et al.: Wpływ otyłości na rokowanie i ryzyko powikłań u pacjentów z chorobą pnia lewej tętnicy wieńcowej leczonych kardiochirurgicznie. Pol Przegl Kardiol. 2012, 14 (1), 29-36.

13. Shafir R., Weiss J., Herman O., Cohen N., Stern D., Igra Y.: Faulty sternotomy and complications after median sternotomy. J Thorac Cardiovasc Surg. 1988, 96 (2), 310-313.
14. Bitner M., Jaszewski R.: Rozejścia mostka po operacjach w krążeniu pozaustrojowym w umiarkowanej hipotermii (lata 1987-1994) i w normotermii ogólnej (lata 1995-2000). Clin Exp Med Lett. 2005, 46 (3), 47-50.

15. Gualis J., Flórez S., Tamayo E., Alvarez F.J., Castrodeza J., Castaño M.: Risk factors for mediastinitis and endocarditis after cardiac surgery. Asian Cardiovasc Thorac Ann. 2009, 17 (6), 612-616.

16. Wouters R., Wellens F., Vanermen H., De Geest R., Degrieck I., De Meerleer F.: Sternitis and mediastinitis after coronary artery bypass grafting. Analysis of risk factors. Tex Heart Inst J. 1994, 21 (3), 183-188.

17. Abid Q., Podila S.R., Kendall S.: Sternal dehiscence after cardiac surgery and ACE type I inhibition. Eur J Cardiothorac Surg. 2001, 20 (1), 203-204.

18. El Oakley R.M., Wright J.E.: Postoperative mediastinitis: classification and management. Ann Thorac Surg. 1996, 61 (3), 1030-1036.

19. Bottio T., Rizzoli G., Vida V., Casarotto D., Gerosa G.: Double crisscross sternal wiring and chest wound infections: a prospective randomized study. J Thorac Cardiovasc Surg. 2003, 126 (5), 1352-1356.

20. Furnary A.P., Gao G., Grunkemeier G.L., Wu Y., Zerr K.J., Bookin S.O. et al.: Continuous insulin infusion reduces mortality in patients with diabetes undergoing coronary artery bypass grafting. J Thorac Cardiovasc Surg. 2003, 125 (5), 1007-1021. 